\title{
Structure, Physico-chemical and Microbiological Properties of Ozone-oxidized Wheat, Corn, Potato and Rice Starches
}

\author{
Hatice Çatal and Şenol İbanoğlu \\ Department of Food Engineering, Faculty of Engineering, University of Gaziantep, TR 27310, Gaziantep, Turkey
}

Received: December 22, 2011 / Published: April 20, 2012.

\begin{abstract}
A limited number of studies have been conducted on the effects of ozone use on cereal and its components. Starch, an important natural macromolecule, is an essential component of cereals. In present study, the effects of ozone on the structure, physico-chemical and microbiological properties of wheat, corn, potato and rice starches were investigated. Wheat starch, corn starch, potato starch and rice starch water mixtures were prepared in the ratio of 1:9 (dry sample to water ratio) and treated with ozone at a rate of $60 \mathrm{~g} / \mathrm{h}$ for 1 hour, while unozonated samples were used as controls. Light microscopy represented that the structures of corn and potato starch samples were affected by $1 \mathrm{hr}$ ozonation rather than the structures of wheat and rice starch samples. Colour of ozone-oxidized wheat, corn and potato starch samples could meet the consumer preference due to the higher lightness, higher whiteness and lower chroma value. However, high chroma, high yellownes and low whiteness values of ozonated rice starch is not adequate for consumer desire. Microbiological analysis showed that $1 \mathrm{hr}$ ozonation reduced the total bacteria and mould/yeast counts significantly for all wheat, corn, potato and rice starch samples $(P<0.05)$ due to most probably the reduced $\mathrm{pH}$ of samples. Ozonation can be an alternative modification technique, but further research is needed to understand the certain benefits and limitations of ozone applications on starch oxidation for human safety and health.
\end{abstract}

Key words: Ozone, starch, structure, colour, pH, microbiology.

\section{Introduction}

Ozone is a natural substance found in our atmosphere, but it can also be produced synthetically. Ozone is a form of oxygen that includes 3 atoms $\left(\mathrm{O}_{3}\right)$ compared to the standard $2\left(\mathrm{O}_{2}\right)$ in a molecule of oxygen. Structurally, the three atoms of oxygen are in the form of an isoscales triangle with an angle of 116.8 degree between the $2 \mathrm{O}-\mathrm{O}$ bonds. The distance between the bond oxygen atoms is 1.27 angstrons. Ozone is derived from the Greek word "Ozein” which means "to smell." Ozone as a gas is blue; both liquid (-111.9 ${ }^{\circ} \mathrm{C}$ at 1 atmosphere) and solid ozone $\left(-192.7^{\circ} \mathrm{C}\right)$ are an opaque blue-black colour [1]. It is relatively unstable gas at normal temperatures and

Corresponding author: Hatice Çatal, Ph.D., researcher, research field: ozonation of starch. E-mail: pekmez@gantep.edu.tr. pressures, is partially soluble in water, has a characteristic pungent odour, and is the strongest disinfectant currently available for contact with foods [2]. The relatively high (+2.075 V) electrochemical potential $\left(\mathrm{E}^{\circ}\right.$, Volt) indicates that ozone is a very favorable oxidizing agent [3]. Ozone is generated by the exposure of air or another gas containing normal oxygen to a high-energy source. High-energy sources convert molecules of oxygen to molecules of ozone (Fig. 1) [4]. Ozone must be manufactured on site for immediate use, since it is unstable and quickly decomposes to normal oxygen. The half-life of ozone in distilled water at $20^{\circ} \mathrm{C}$ is about 20 to $30 \mathrm{~min}$ [5].

The application of ozone in water treatment is widespread throughout the world. Ozone has been shown to be a powerful oxidant and disinfectant in water treatments. So far, ozone has been applied mainly 


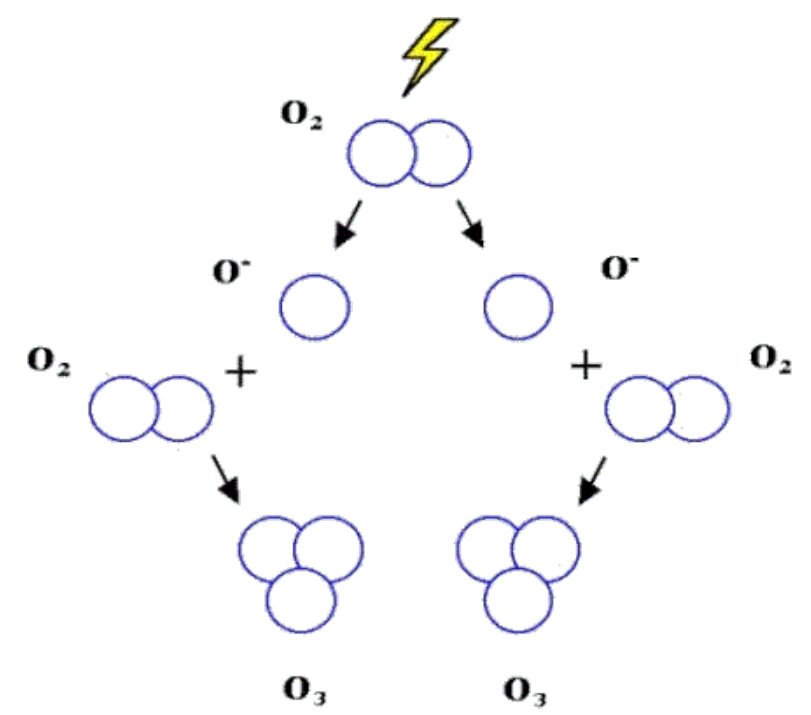

Fig. 1 Generation of ozone molecule [4].

to the treatment of drinking water [6-9]. However, previous laboratory works have also shown that ozonation may be recommended as a technology to improve wastewater treatment units, such as sedimentation, chemical or biological oxidation [10].

Ozone was discovered by C. F. Schonbein in 1839 and was first used commercially in water supply treatment in 1907 [11]. Ozone was approved as generally recognized as safe (GRAS) as a disinfectant for foods by the Food and Drug Administration (FDA) of the U. S. in 1997 and the FDA allowed for the use of ozone as a direct contact food sanitizing agent in 2001 [3]. Food industry has shown a great interest in using ozone to enhance the shelf-life and safety of food products [12-16].

Starch (an integral part of cereals) is one of the very important biopolymers widely used in the food industry [17]. Starch affects texture, viscosity, gel formation, adhesion, binding, moisture retention, film formation and product homogeneity. It is used mainly in soups, sauces and gravies, bakery products, dairy confectionery, snacks, batters and coatings and meat products [18].

The variation in the size and shape of starch granules is related to the biological origin [19]. By putting different forces on the molecules, the molecules can change shape from their normal shape and alter related properties of starch (binding, colour, pasting, structure, gelatinization and microbial properties). The microbial population of starch is important for the overall quality and shelf-life of product. Starch with a high number of micro-organisms can reduce the storage life due to undesired appearance, flovour and odour. Total bacterial count and mould/yeast count are generally used for calculation of microbial load of starch by aerobic spread-plate technique described by Jay [20]. Colour and $\mathrm{pH}$ concepts are the basic physico-chemical properties of starch granules. Colour is an important attribute to the food industry. Consumers frequently look at a product and make a judgement decision largely based on overall appearance including colour. Often colour and flavour are directly related. The colour scales that are most widely used by the cereal industry are the Hunter L, a, $b$ [21]. The concentration of hydrogen ions in a solution is also important. As the hydrogen ions are positively charged, they alter the charge environment of other molecules in solution [22].

There is not any available data about the effect of ozone use on the structure, phsico-chemical and microbial properties of wheat, corn, potato and rice starches. In current study, the effects of ozonation on the physico-chemical (colour; L, a, b, chroma, hue, whiteness, total color difference and $\mathrm{pH}$ ) and microbiological properties (total bacteria and yeast/mould counts) of wheat, corn, potato and rice starches were investigated.

\section{Materials and Methods}

\subsection{Materials}

Wheat, corn, potato and rice starches were used as raw materials. Starch samples were purchased from the market (Migros A.Ş., İstanbul, Turkey). The moisture contents of starch samples were determined by a moisture analyzer (Metler Toledo, MJ33 Moisture analyzer, Switzerland). 


\subsection{Ozonation of Starches}

Ozone was obtained by an ozone generator (OMS Model Ozone Generator, İzmir, Turkey) using the coronal-discharge method (Fig. 2). The generator has a mixing part, a degasser for removing of undissolved ozone in water, a redox control (ORP) system and an integrated oxygen unit using atmospheric air. It has a maximum ozone production capacity of $60 \mathrm{~g} / \mathrm{h}$. Samples were ozonated in a $500 \mathrm{~mL}$ glass gas washing bottle (Fig. 3). Gas is directed from the generator to the bottle by a connection whose end was equipped with a gas disperser to increase solubility and diffusion by creating bubbles. Dissolved ozone concentration was determined by oxidation/reduction potential (ORP). It was converted to ppm by using a calibration table (Table 1). Undisssolved ozone gas was driven to the atmosphere by a discharging tube.

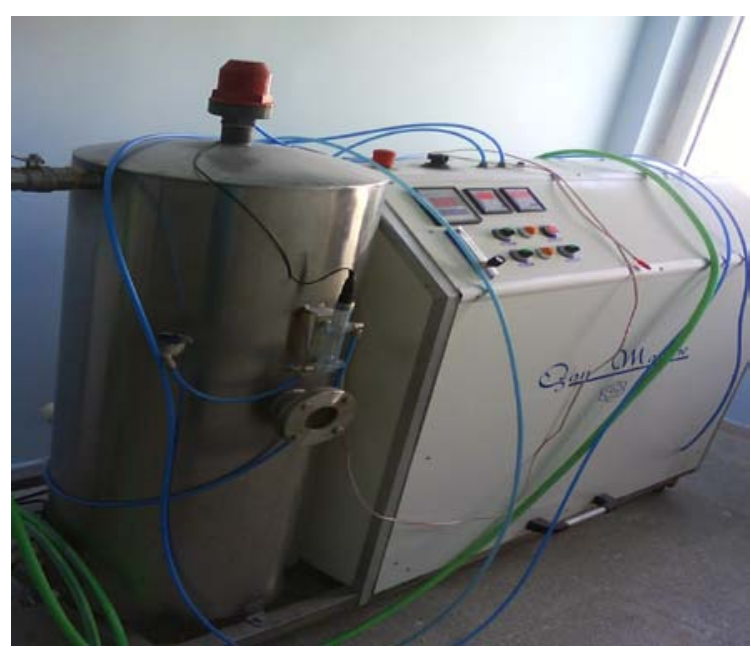

Fig. 2 Photograph of ozone generator.

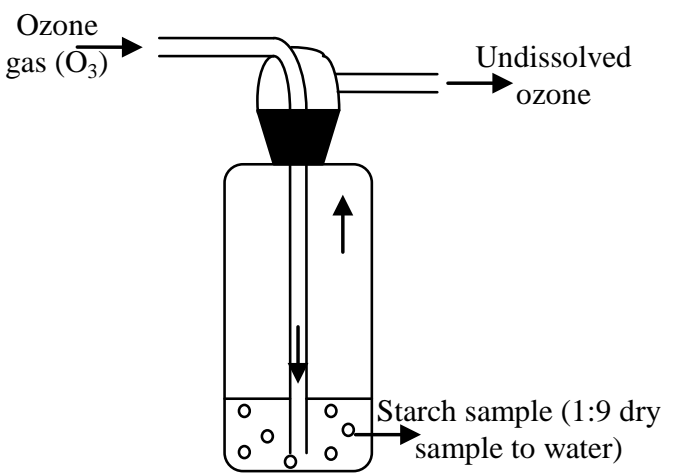

Fig. 3 Schematic diagram of gas washing bottle for ozonation.
Table 1 Calibration table of conversion of ozone concentration from ORP to $\mathrm{ppm}$.

\begin{tabular}{|c|c|}
\hline $\mathrm{mV}$ (orp) & $\mathrm{ppm}(\mathrm{mg} / \mathrm{L})$ \\
\hline 100 & 0 \\
\hline 200 & 0.04 \\
\hline 300 & 0.08 \\
\hline 400 & 0.13 \\
\hline 500 & 0.16 \\
\hline 600 & 0.20 \\
\hline 700 & 0.22 \\
\hline 750 & 0.25 \\
\hline 800 & 0.39 \\
\hline 860 & 0.50 \\
\hline 875 & 1.00 \\
\hline 900 & 1.25 \\
\hline 925 & 1.50 \\
\hline 950 & 1.75 \\
\hline 975 & 2.00 \\
\hline 1,000 & 2.25 \\
\hline 1,025 & 2.50 \\
\hline 1,050 & 2.75 \\
\hline 1,075 & 3.00 \\
\hline 1,100 & 3.25 \\
\hline 1,125 & 3.50 \\
\hline 1,150 & 3.75 \\
\hline 1,175 & 4.00 \\
\hline 1,200 & 4.25 \\
\hline 1,225 & 4.50 \\
\hline 1,250 & 4.75 \\
\hline 1,275 & 5.00 \\
\hline 1,300 & 5.25 \\
\hline 1,325 & 5.50 \\
\hline 1,350 & 5.75 \\
\hline 1,375 & 6.00 \\
\hline 1,400 & 6.25 \\
\hline 1,425 & 6.50 \\
\hline 1,450 & 6.75 \\
\hline 1,475 & 7.00 \\
\hline 1,500 & 7.25 \\
\hline 1,525 & 7.50 \\
\hline 1,550 & 7.75 \\
\hline 1,575 & 8.00 \\
\hline 1,600 & 8.25 \\
\hline
\end{tabular}

Wheat starch-water, corn starch-water, potato starch-water and rice starch-water mixtures were prepared in the ratio of 1:9 (dry sample to distlilled water ratio). The prepared wheat starch-water, corn starch-water, potato starch-water and rice starch-water mixtures were treated with ozone at a rate of $60 \mathrm{~g} / \mathrm{h}$ in 
the bottle for 1 hour while unozonated starch samples were used as controls.

\subsection{Light Microscopy Observation}

The shape of control and ozonated wheat, corn, potato and rice starch granules were observed using a light microscope (Model BX51, Olympus Corp., Tokyo, Japan) equipped with a $100 \mathrm{~W}$ halogen light source. $10 \mu \mathrm{L}$ sample was placed on a slide covered by a cover slip to observe at a magnification of $20 \times$. A Pixera camera (Model PVC 100 C, Los Gatos, CA, USA) was used to acquire the images.

\subsection{Starch Colour}

Colours of all control and ozonated wheat, corn, potato and rice starches samples were measured with a HunterLab ColorFlex (A60-1010-615 Model Colorimeter, Hunter lab, Reston VA). A white standard plate $\left(\mathrm{L}_{0}=93.01, \mathrm{a}_{0}=-1.11, \mathrm{~b}_{0}=1.30\right)$ was used to calibrate the colorimeter. Triplicate measurements for $\mathrm{L}$, $\mathrm{a}$, and $\mathrm{b}$ were done where $\mathrm{L}$ is the brightness coefficient from dark (0) to bright (0), $a$ is the coefficient from green (-) to red $(+)$ and $b$ is the coefficient from blue (-) to yellow (+). Chroma (Eq. 1), hue (Eq. 2), whiteness (Eq. 3) and total colour difference (TCD; Eq. 1) were obtained by following equations:

$$
\begin{gathered}
\text { Chroma }=\sqrt{\left(a^{2}+b^{2}\right)} \\
\text { Hue }=\arctan \frac{b}{a} \\
\text { Whiteness }=100-\sqrt{\left(100-L^{2}\right)+a^{2}+b^{2}} \\
\text { TCD }=\sqrt{\left(L_{o}-L\right)^{2}+\left(a_{o}-a\right)^{2}+\left(b_{o}-b\right)^{2}}
\end{gathered}
$$

\section{$2.5 \mathrm{pH}$ Measurement}

The $\mathrm{pH}$ values of control and ozonated wheat, corn, potato and rice starches were determined by a pH-meter (Hanna instruments, pH 211, Microprocessor $\mathrm{pH}$-meter, Portugal). All $\mathrm{pH}$ analyses of starch samples were carried out in triplicate.

\subsection{Microbial Analysis (Total Bacteria and} Mould/yeast Counts)

Serial dilutions from $10^{-1}$ to $10^{-4}$ levels were made from control and ozonated wheat, corn, potato and rice starch samples. The aerobic spread-plate technique was carried out for both total bacterial count and mould/yeast count.

Aerobic plate count agar (PCA; Merck, Darmstadt, Germany) was used for the total bacteria analysis. The inoculated samples $(0.2 \mathrm{~mL})$ were incubated at $37^{\circ} \mathrm{C}$ for 24-48 hr. Potato dextrose agar (PDA; Merck, Darmstadt, Germany) was used for the mold and yeast count analysis. The inoculated samples $(0.2 \mathrm{~mL})$ were incubated at $25{ }^{\circ} \mathrm{C}$ for 2-5 days. The plates were counted as colony forming units (cfu) and expressed as $\log \mathrm{cfu} / \mathrm{g}$. All analyses were carried out in triplicate for each dilution.

\subsection{Statistical Analysis}

Statistical analysis (SPSS 13.0 software for Windows) was performed to compare the experimental results under the ozonation treatment including untreated control by using one-factor analysis of variance (ANOVA). All experimental values are at least mean of triplicate determination. In order to determine the data that are significantly different from each other, Duncan multiple range test method was applied. Trends were considered significant when means of compared parameters differed at $P<0.05$ significance level.

\section{Results and Discussion}

\subsection{Structure Analysis by Light Microscopy}

Wheat, corn, potato and rice starch granules were examined under light microscope to investigate the structure (granule shape) changes after $1 \mathrm{hr}$ ozonation. The shape images of both control and ozonated starch granules were shown in Figs. 4-7. Control starch samples showed that the granules are round to polygonal in shape similar to the shapes reported in the 


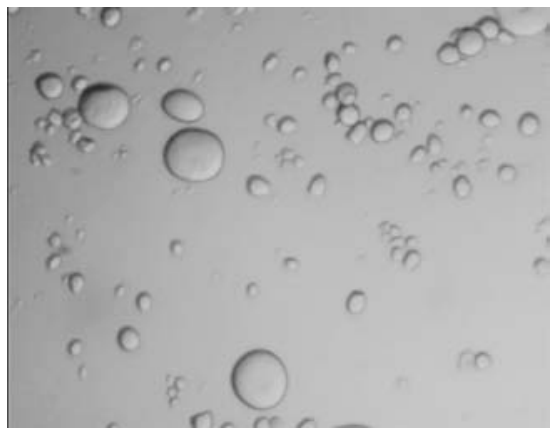

Control wheat starch

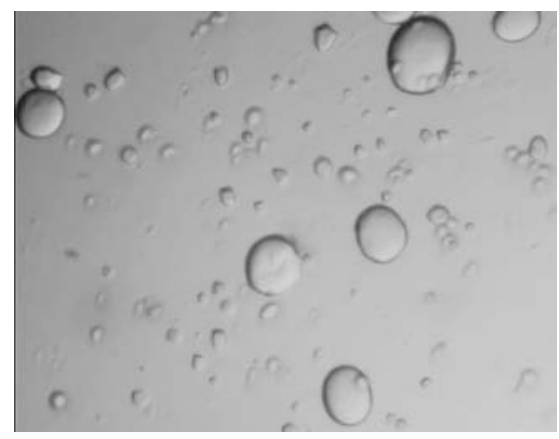

1 hr ozonated wheat starch

Fig. 4 Light microscopy $(20 \times)$ of control and $1 \mathrm{hr}$ ozonated wheat starch granules.

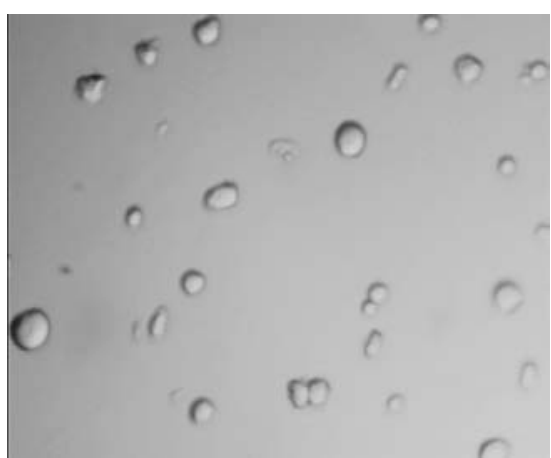

Control corn starch

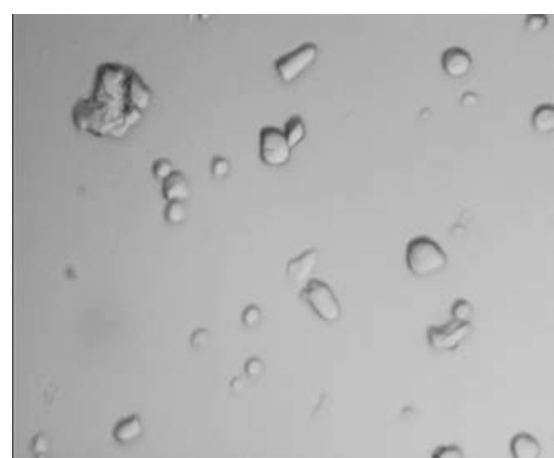

1 hr ozonated corn starch

Fig. 5 Light microscopy $(20 \times)$ of control and $1 \mathrm{hr}$ ozonated corn starch granules.

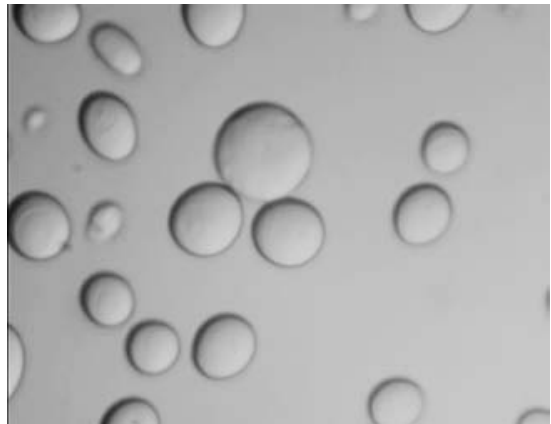

Control potato starch

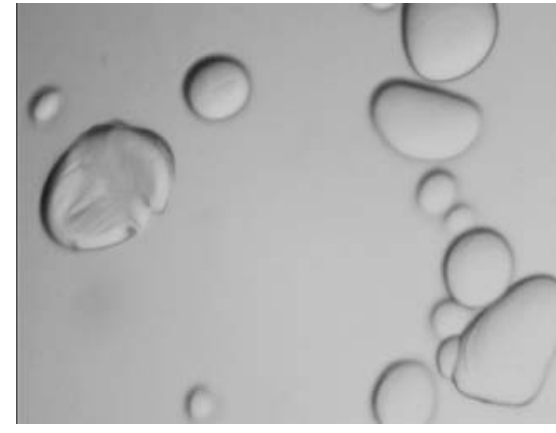

$1 \mathrm{hr}$ ozonated potato starch

Fig. 6 Light microscopy $(20 \times)$ of control and 1 hr ozonated potato starch granules.

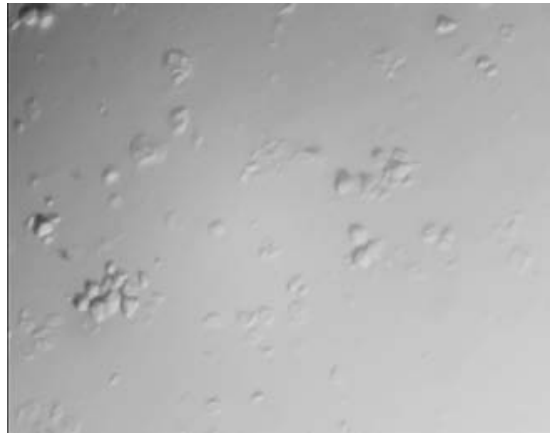

Control rice starch

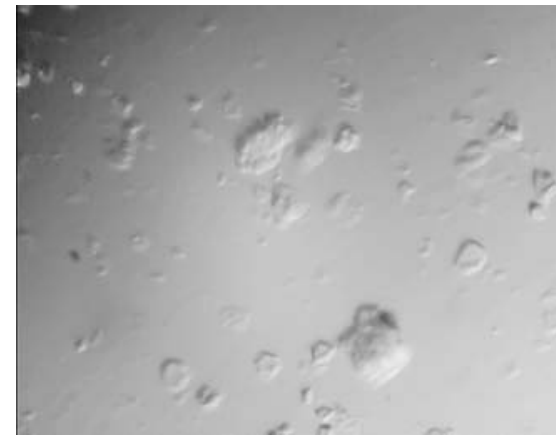

1 hr ozonated rice starch

Fig. 7 Light microscopy $(20 \times)$ of control and 1 hr ozonated rice starch granules. 
literature. The granule surface is relatively smooth and free from pores, cracks or fissures [17, 23].

Wheat starch granules are roughly spherical or polygonal in shape, while potato starch granules are oval and irregular or cuboidal in shape. The starch granules are angular-shaped for corn, and pentagonal and angular-shaped for rice [24]. In our present study, shape of unozonated wheat, corn, potato and rice starch granules under light microscope were observed identically to that study (Figs. 4-7).

Due to the irregular shape and small size of rice starch granules, changes in the granule shape and surface caused by ozonation were not obvious (Fig. 7). Similarly, any noticible change was not observed for ozonated wheat starch sample (Fig. 4). However, changes in the granule shape and surface induced by the ozonation were visually distinct for corn and potato starch granules (Figs. 5 and 6). Similar observations under scanning electron microcope (SEM) were obtained by Liu et al. [17] for the study of under high pressure treatments for wheat and potato starches and by Hui et al. [25] for modified potato starch.

The average granule size ranges from 1 to $20 \mathrm{~mm}$ for small and 20 to $110 \mathrm{~mm}$ for large potato starch granules. The average size of individual corn starch granules ranges from 1 to $7 \mathrm{~mm}$ for small and 15 to $20 \mathrm{~mm}$ for large granules. The rice starch granules range from 3 to $5 \mathrm{~mm}$ in size. At maturity, wheat endosperm contains two types of starch granules: large A- and small B-type. A-type granules are with diameters ranging from 10 to $35 \mathrm{~mm}$. On the other hand, B-type starch granules are ranging from 1 to $10 \mathrm{~mm}$ in diameter [24]. It is obvious that granule sizes of potato and corn starches are greater than wheat and rice starches.

Ozone treatment resulted in swollen starch granules for corn and potato starch samples (Figs. 5 and 6). This swollen condition could be resulted from large granule sizes of corn and potato starches. In this way, ozone could diffuse and penetrate into starch granules easily. Light microscopy performance for starch samples represented that ozonation is more effective on the greater sizes of starch granules. In other words, the structures of corn and potato starch samples were affected by $1 \mathrm{hr}$ ozone treatment rather than the structures of wheat and rice starch samples.

\subsection{Physico-chemical Properties}

Water holds more ozone than air, since ozone needs to remain in the water long enough to disperse fully [26]. Ozonated water penetrates into the starch granule easier than ozonated air. That is why all wheat starch-water, corn starch-water, potato starch-water and rice starch-water mixtures were ozonated in the presence of water (1:9; dry sample to distlilled water ratio).

Colour is an important quality parameter on starch due to the presence of phenolic compounds, ascorbic acid and caratone. There must not be any pigmentation reducing the quality and acceptibility of starch [27].

The colours of the sample were evaluated by the 3-dimensional scales; $\mathrm{L}$, a and $\mathrm{b}$. The $\mathrm{L}, \mathrm{a}, \mathrm{b}$ type of scales simulate this as: L (lightness) axis- 0 is black, 100 is white; a (red-green) axis-positive values are red, negative values are green and 0 is neutral; b (yellow-blue) axis-positive values are yellow, negative values are blue and 0 is neutral. The measured colour parameters of control and ozonated wheat, corn, potato and rice starch samples were demostrated in Table 2. According to these data, there are significant differences between the $\mathrm{L}$ values of control and ozonated wheat, corn and potato starch samples $(P<0.05) .1 \mathrm{hr}$ ozonation caused significant increase in the brightness ( $\mathrm{L}$ value) of wheat, corn and potato starches, while the brightness ( $\mathrm{L}$ value) of control rice starch was not affected by ozonation significantly $(P>0.05)$. Beside this, the a and $\mathrm{b}$ values of all control starch samples are significantly different from ozonated starch samples $(P<0.05)$ by the way of decreases in the values except the $b$ value of ozonated rice stach. Yellowness of $1 \mathrm{hr}$ ozonated rice starch was increased significantly as an unexpected result $(P<0.05)$. 
The calculated colour parameters (chroma, hue, whiteness and total colour difference; TCD) of control and ozonated wheat, corn, potato and rice starch samples were listed in Table 3. Chroma values of wheat, corn and potato starches were reduced by $1 \mathrm{hr}$ ozonation, while chroma value of rice starch was increased significantly $(P<0.05)$. Calculated hue angles of ozonated starch samples are also different significantly from control ones $(P<0.05)$. Whiteness of all $1 \mathrm{hr}$ ozonated starch samples are significantly higher than control starch samples except ozonated rice starch $(P<0.05)$. Total colour difference (TCD) for ozonated starch samples are less than the control starches. However, TCD for ozonated rice is significantly higher than control $(P<0.05)$.

A low value for chroma and a high value for lightness for starch are widely accepted by consumer [28-30]. Concerning the colour of flours, ozone in gas or aqueous form has the ability to decolorize some food components by oxidizing the pigments [31]. In present study, colour of ozonated wheat, corn and potato starch samples could meet the consumer preference due to the higher lightness, whiteness and lower chroma value caused by ozone oxidation modication. In contrast, the colour parameters (high chroma, high yellownes and low whiteness) of ozonated rice starch are not adequate for consumer desire. This could be caused by difficult diffusion of ozone into smaller size of rice starch granules than the other starch types.

$\mathrm{pH}$ value is one of the physico-chemical properties of starch [29]. The $\mathrm{pH}$ value is a measure of the acidity or basicity of a solution. The $\mathrm{pH}$ values were determined for all control and $1 \mathrm{hr}$ ozonated starchwater mixtures (Table 2). It was observed that the $\mathrm{pH}$ of control samples were found very near neutrality. However, $1 \mathrm{hr}$ ozonation process caused the $\mathrm{pH}$ 's of wheat, corn, potato and rice starch samples decrease

Table 2 Colour parameter and pH values of control and $1 \mathrm{hr}$ ozonated starch-water mixtures.

\begin{tabular}{lllll}
\hline Starch sample & $\mathrm{L}$ & $\mathrm{a}$ & $\mathrm{b}$ & $\mathrm{pH}$ \\
\hline Control wheat starch & $87.73 \pm 0.08 \mathrm{c}$ & $0.02 \pm 0.01 \mathrm{f}$ & $4.13 \pm 0.49 \mathrm{e}$ & $3.56 \pm 0.01 \mathrm{~d}$ \\
Ozonated wheat starch & $90.55 \pm 0.01 \mathrm{de}$ & $-0.47 \pm 0.05 \mathrm{c}$ & $2.26 \pm 0.18 \mathrm{~d}$ & $1.46 \pm 0.03 \mathrm{a}$ \\
Control corn starch & $89.57 \pm 0.17 \mathrm{~d}$ & $-1.36 \pm 0.02 \mathrm{~b}$ & $6.68 \pm 0.02 \mathrm{~g}$ & $5.48 \pm 0.07 \mathrm{e}$ \\
Ozonated corn starch & $91.70 \pm 0.13 \mathrm{e}$ & $-0.46 \pm 0.02 \mathrm{c}$ & $0.26 \pm 0.05 \mathrm{a}$ & $2.17 \pm 0.03 \mathrm{c}$ \\
Control potato starch & $77.57 \pm 2.11 \mathrm{a}$ & $-0.06 \pm 0.02 \mathrm{e}$ & $1.57 \pm 0.06 \mathrm{c}$ & $6.60 \pm 0.05 \mathrm{~g}$ \\
Ozonated potato starch & $82.04 \pm 0.58 \mathrm{~b}$ & $-0.15 \pm 0.01 \mathrm{~d}$ & $0.86 \pm 0.01 \mathrm{~b}$ & $1.41 \pm 0.06 \mathrm{a}$ \\
Control rice starch & $86.93 \pm 0.32 \mathrm{c}$ & $-0.48 \pm 0.02 \mathrm{c}$ & $5.79 \pm 0.07 \mathrm{f}$ & $6.04 \pm 0.07 \mathrm{f}$ \\
Ozonated rice starch & $87.27 \pm 0.35 \mathrm{c}$ & $-2.01 \pm 0.03 \mathrm{a}$ & $9.55 \pm 0.15 \mathrm{~h}$ & $1.76 \pm 0.05 \mathrm{~b}$ \\
\hline
\end{tabular}

Values followed by the different letter in the same column are significantly different $(P<0.05)$. Means $( \pm$ standard deviation) are based on triplicate analyses. $\mathrm{L}=$ lightness (black/white), $\mathrm{a}=$ green/red and $\mathrm{b}=$ blue/yellow.

Table 3 Calculated chroma, hue, whiteness and TCD values.

\begin{tabular}{lllll}
\hline Starch sample & Chroma & Hue & Whiteness & TCD \\
\hline Control wheat starch & $4.13 \pm 0.49 \mathrm{~d}$ & $-89.68 \pm 0.15 \mathrm{~d}$ & $87.04 \pm 0.23 \mathrm{de}$ & $6.10 \pm 0.30 \mathrm{~b}$ \\
Ozonated wheat starch & $2.30 \pm 0.19 \mathrm{c}$ & $-78.16 \pm 0.55 \mathrm{~b}$ & $90.27 \pm 0.06 \mathrm{f}$ & $2.71 \pm 0.07 \mathrm{a}$ \\
Control corn starch & $6.81 \pm 0.02 \mathrm{f}$ & $-78.51 \pm 0.16 \mathrm{~b}$ & $87.54 \pm 0.14 \mathrm{e}$ & $6.38 \pm 0.92 \mathrm{bc}$ \\
Ozonated corn starch & $0.53 \pm 0.01 \mathrm{a}$ & $-28.93 \pm 0.6 .73 \mathrm{c}$ & $91.68 \pm 0.13 \mathrm{~g}$ & $1.79 \pm 0.12 \mathrm{a}$ \\
Control potato starch & $1.57 \pm 0.06 \mathrm{~b}$ & $-87.91 \pm 0.85 \mathrm{a}$ & $77.51 \pm 2.11 \mathrm{a}$ & $15.47 \pm 2.10 \mathrm{e}$ \\
Ozonated potato starch & $0.87 \pm 0.01 \mathrm{a}$ & $-80.06 \pm 0.82 \mathrm{~b}$ & $82.02 \pm 0.58 \mathrm{~b}$ & $11.01 \pm 0.58 \mathrm{~d}$ \\
Control rice starch & $5.80 \pm 0.07 \mathrm{e}$ & $-85.28 \pm 0.23 \mathrm{a}$ & $85.69 \pm 0.27 \mathrm{~d}$ & $7.58 \pm 0.22 \mathrm{c}$ \\
Ozonated rice starch & $9.76 \pm 0.14 \mathrm{~g}$ & $-78.11 \pm 0.22 \mathrm{~b}$ & $83.95 \pm 0.26 \mathrm{c}$ & $10.09 \pm 0.19 \mathrm{~d}$
\end{tabular}

Values followed by the different letter in the same column are significantly different $(P<0.05)$. Means $( \pm$ standard deviation) are based on triplicate analyses. TCD = Total colour difference. 
very sharply $(P<0.05)$ in the presence of water. Ozonated starch-water mixtures became acidic. Low $\mathrm{pH}$ value of ozonated starch samples could be an advantageous due to prevention of growth of many microorganisms and could provide longer shelf-life for starch products.

\subsection{Microbiological Properties}

Microbiological analysis showed that $1 \mathrm{hr}$ ozonation reduced the total bacteria and mould/yeast counts significantly for all wheat, corn, potato and rice starch samples $(P<0.05)$. The average values for triple studied samples were demonstrated in Table 4. These results are most probably because of the reduced $\mathrm{pH}$ 's of samples during the ozonation process.

Bacterial and fungal contaminated in flour, including spores of Bacillus, Coliform bacteria, Micrococcus, Flavobacterium, Alcaligenes, Serratia, Aspergillus and Penicillium. Naito and Takahara [32] reported that ozonation can reduce levels of the natural microflora and contaminated microorganisms. The microbial of wheat kernels before milling is important for final microbial quality of the resulting flours. A high number of microorganisms reduces the storage life of the flours and causes a reduction in the overall quality of the flours. İbanoğlu [31, 33] suggested that ozonated water can be successfully used for wheat washing and tempering to reduce microbial populations. Considering that ozone is approximately 30,000 times more effective on
Escherichia coli than chlorine, ozone can be an alternative for disinfectants used in proceesing in water. Also, Tiwari et al. [34] demonstrated that ozone is an effective greener alternative against a range of pests, micro-organisms and mycotoxins.

Ozone is a powerful antimicrobial agent that is suitable for application in food in the gaseous and aqueous states. Molecular ozone or its decomposition products (for example, hydroxyl radical) inactivate microorganisms rapidly by reacting with intracellular enzymes, nucleic material and components of their cell envelope, spore coats, or viral capsids [5]. The antimicrobial efficacy of ozonation can be enhanced considerably when it is combined with other chemicals (e.g. $\mathrm{H}_{2} \mathrm{O}_{2}$ ) or physical (e.g. UV-C radiation) treatments [35].

Low microbial population is important for the quality of starch. Ozonation process can eliminate contamination of bacteria and fungi during the production of starch and can provide safer starch product. The longer the shelf-life means the more preferable the starch and the more marketing for the starch industry.

\section{Conclusion}

The effects of ozone on the structure, physico-chemical and microbiological properties of wheat starch, corn starch, potato starch and rice starch were investigated in the present work and the results were provided below: $1 \mathrm{hr}$ ozonation caused corn and potato starch granules to be swollen. Ozone could diffuse

Table 4 Total bacteria and mould/yeast counts of control and $1 \mathrm{hr}$ ozonated starch-water mixtures (log cfu/g).

\begin{tabular}{lll}
\hline Starch sample & Total bacteria & Mold/yeast \\
\hline Control wheat starch & $5.24 \pm 0.13 \mathrm{c}$ & $5.09 \pm 0.04 \mathrm{c}$ \\
Ozonated wheat starch & $3.10 \pm 0.17 \mathrm{~b}$ & $0.66 \pm 1.15 \mathrm{a}$ \\
Control corn starch & $5.41 \pm 0.13 \mathrm{c}$ & $5.35 \pm 0.04 \mathrm{c}$ \\
Ozonated corn starch & $3.01 \pm 0.27 \mathrm{~b}$ & $1.95 \pm 0.24 \mathrm{~b}$ \\
Control potato starch & $5.56 \pm 0.02 \mathrm{c}$ & $5.37 \pm 0.06 \mathrm{c}$ \\
Ozonated potato starch & $2.23 \pm 0.20 \mathrm{a}$ & $0 \pm 0.00 \mathrm{a}$ \\
Control rice starch & $6.63 \pm 0.28 \mathrm{~d}$ & $5.76 \pm 0.03 \mathrm{c}$ \\
Ozonated rice starch & $2.86 \pm 0.14 \mathrm{~b}$ & $0 \pm 0.00 \mathrm{a}$ \\
\hline
\end{tabular}

Values followed by the different letter in the same column are significantly different $(P<0.05)$. Means $( \pm$ standard deviation) are based on triplicate analyses. 
and penetrate into large size of starch granules easily. Light microscopy represented that ozonation is more effective on the greater sizes of starch granules. Significant increases in brightness and whiteness were observed for ozonated wheat, corn and potato starch samples. However, ozone did not change the brightness of rice starch. Chroma values of all control starch samples are significantly different from ozonated sample ones in terms of decreases in the values. Higher lightness and lower chroma values of ozonated starch samples could rise the consumer desire. Ozone treatment reduced not only total bacteria, but also mould/yeast counts significantly for all wheat, corn, potato and rice starch samples. The results are most probably due to the reduced pH's of samples during the ozonation process. $1 \mathrm{hr}$ ozonation got it right to decrease the pH's of wheat, corn, potato and rice starch samples significantly. Prevention of growth of many microorganisms due to low $\mathrm{pH}$ value of ozonated starch samples could provide longer shelf-life for starch products. Therefore, ozonation could be used as an alternative technique to modify starch by oxidation. However, further research is required to understand the certain benefits and limitations of ozone applications on starch oxidation for human safety and health.

\section{References}

[1] B. Hunter, Ozone applications: An in depth discussion, Health Freedom News 14 (1995) 2.

[2] K. Muthukumarappan, F. Halaweish, A.S. Naidu, Ozone, in: A.S. Naidu (Ed.), Natural Food Anti-Microbial Systems, CRC Pres, Boca Raton, FL., 2000, pp. 783-800.

[3] A.K. Mahapatra, K. Muthukumarappan, J.L. Julson, Applications of ozone, bacteriocins and irradiation in food processing: A review, Critic. Rev. Food Sci. Nutr. 45 (6) (2005) 447-461.

[4] http://www.ozoneapplications.com/info/ozone_corona_di scharge.htm.

[5] M.A. Khadre, A.E. Yousef, J.G. Kim, Microbial aspects of ozone applications in food: A review, J. Food Sci. 66 (9) (2001) 1242-1252.

[6] R. Chand, D.H. Bremner, K.C. Namkung, P.J. Collier, P.R. Gogate, Water disinfection using the novel approach of ozone and a liquid whistle reactor, Biochem. Eng. J. 35 (2007) 357-364.

[7] B. Kasprzyk-Hordern, U. Raczyk-Stanisławiak, J. Świetlik, J. Nawrocki, Catalytic ozonation of natural organic matter on alumina, App. Catalysis B: Environmental 62 (2006) 345-358.

[8] U. von Gunten, Ozonation of drinking water: Part I. Oxidation kinetics and product formation, Water Res. 37 (2003) 1443-1467.

[9] U. von Gunten, Ozonation of drinking water: Part II. Disinfection and by-product formation in presence of bromide, iodide or chlorine, Water Res. 37 (2003) 1469-1487.

[10] F.J. Beltrán, J.F. García-Araya, P.M. Álvarez, pH sequential ozonation of domestic and wine-distillery wastewaters, Water Res. 35 (4) (2001) 929-936.

[11] U. Kogelschatz, Advanced ozone generation, in: S. Stucki (Ed.), Process Technologies for Water Treatment, Plenum Publishers, New York, 1988, pp. 87-120.

[12] H. Çatal, Ş. İbanoğlu, Ozonation of foods, Elect. J. Food Tech. 5 (3) (2010) 47-55.

[13] D. Graham, Use of ozone for food processing, Food Tech. 51 (6) (1997) 72-73.

[14] J.G. Kim, A.E. Yousef, S. Dave, Application of ozone for enhancing the microbiological safety and quality of foods: A review, J. Food Protect. 62 (1999) 1071-1087.

[15] J.G. Kim, A.E. Yousef, M.A. Khadre, Ozone and its current and future application in the food industry, Adv. Food Nutr. Res. 45 (2003) 167-218.

[16] R.G. Rice, J.W. Farquhar, L.J. Bollyky, Review of the applications of ozone for increasing storage times of perishable foods, Ozone: Sci. Eng. 4 (3) (1982) 147-163.

[17] Y. Liu, V.O. Selomulyo, W. Zhou, Effect of high pressure on some physicochemical properties of several native starches, J. Food Eng. 88 (2008) 126-136.

[18] B. Kaur, F. Ariffin, R. Bhat, A.A. Karim, Progress in starch modification in the last decade, Food Hydrocol. 26 (2) (2012) 398-404.

[19] K. Svegmark, A.M. Hermansson, Microstructure and rheological properties of composites of potato starch granules and amylose: A comparison of observed and predicted structure, Food Struct. 12 (1993) 181-193.

[20] J.M. Jay, Modern Food Microbiology, Modern Food Chemistry, Van Nostrand Reinhold Company Inc., New York, 1986.

[21] http://www.hunterlab.com/pdf/A5Cereal.pdf.

[22] http://staff.jccc.net/pdecell/chemistry/phscale.html.

[23] S. Khatoon, Y.N. Sreerama, D. Raghavendra, S. Bhattacharya, K.K. Bhat, Properties of enzyme modified corn, rice and tapioca starches, Food Res. Inter. 42 (2009) 1426-1433. 
[24] N. Singh, J. Singh, L. Kaur, N.S. Sodhi, B.S. Gill, Morphological, thermal and rheological properties of starches from different botanical sources, Food Chem. 81 (2003) 219-231.

[25] R. Hui, C. Qi-he, F. Ming-liang, X. Qiong, H. Guo-qing, Preparation and properties of octenyl succinic anhydride modified potato starch, Food Chem. 114 (2009) 81-86.

[26] http://www.silvermedicine.org/ozone-water-bath.html.

[27] F.C.F. Galvez, A.V.A. Resurreccion, The effects of decortication and method of extraction on the physical and chemical properties of starch from mung bean (Vigna radiate (L). Wilczec), J. Food Process. Preserv. 17 (1993) 93-107.

[28] A. Gani, S.S. Haq, F.A. Masoodi, A.A. Broadway, A. Gani, Physico-chemical, morphological and pasting properties of starches extracted from water chestnuts (Trapa natans) from three lakes of Kashmir, India, Brazil, Arch. Bio. Tech. 53 (3) (2010) 731-740.

[29] O.J. Ikegwu, P.E. Okechukwu, E.O. Ekumankana, Physico-chemical and pasting characteristics of flour and starch from Achi Brachystegia eurycoma seed, J. Food Tech. 8 (2) (2010) 58-66.

[30] H.M. Thao, A. Noomhorm, Physiochemical properties of sweet potato and mung bean starch and their blends for noodle production, J. Food Process Tech. 2 (2011) 1-9.

[31] S. Ibanoglu, Wheat washing with ozonated water: Effects on selected flour properties, Inter. J. Food Sci. Tech. 37 (2002) 579-584.

[32] S. Naito, H. Takahara, Ozone contribution in food industry in Japan, Ozone: Sci. Eng. 28 (6) (2006) 425-429.

[33] S. Ibanoglu, Influence of tempering with ozonated water on the selected properties of wheat flour, J. Food Eng. 48 (2001) 345-350.

[34] B.K. Tiwari, C.S. Brennan, T. Curan, E. Gallagher, P.J. Cullen, C.P. O'Donnel, Application of ozone in grain processing, J. Cereal Sci. 51 (2005) 248-255.

[35] D.W. Sun, Emerging Technologies for Food Processing, National University of Ireland, Dublin, Ireland, 2005, p. 694. 